\title{
Public support for democracy: Results from the Comparative Study of Electoral Systems project
}

\author{
Ian McAllister* \\ Research School of Social Sciences, The Australian National University, Canberra, ACT 0200, Australia
}

\begin{abstract}
While democracy looks set to become the global political norm, most studies have analysed the phenomenon from either a micro (voter) or a macro (institutional) perspective. The Comparative Study of Electoral Systems aims to combine these two perspectives in order to address key questions about the process of democratization. This special symposium uses the second CSES module, conducted between 2001 and 2006 in 38 countries, to examine public support for democracy. The eight articles cover three themes in public support for democracy: popular satisfaction with democracy; accountability and system performance; and the participation of social groups. All of the articles underline the importance of understanding the interaction between institutional arrangements and voter behaviour in order to gauge the health of democracy.
\end{abstract}

(C) 2007 Elsevier Ltd. All rights reserved.

There is little disagreement among scholars that the past two decades have seen the greatest experiment in democracy in human history. While exact figures vary, Freedom House estimates that as of 2006, 123 of the world's 192 countries were electoral democracies, although only 90 were classified as being free (Freedom House, 2007). Nevertheless, the spread of electoral democracy has been dramatic, with the number of democracies doubling in just two decades. A wide range of research centres, public opinion surveys and academic projects have converged on this phenomenon of 'third wave democratization' - to use Huntington's phrase to understand its problems and prospects (Huntington, 1991; Doreenspleet, 2000). The 21st century looks set to be the era when democracy - in name at least - becomes the global political norm.

\footnotetext{
* Tel.: +61 (0) 26125 5553; fax: +61 (0) 261253051 .

E-mail address: ian.mcallister@anu.edu.au
}

For the most part, the studies that have examined the process of democratization have done so from either a micro perspective, usually relying on mass public opinion surveys, or a macro perspective, by examining variations in institutional arrangements and practices. This special symposium approaches the question from a different perspective. By utilising the unrivalled resource of the Comparative Study of Electoral Systems (CSES) project, it is possible to analyze patterns of mass political behaviour under varying institutional arrangements, thereby enabling us to address some of the key questions about the process of democratization across the world. The unique capacity of the CSES to trace the interaction between mass political behaviour and institutional structure sets it apart from all of the other cross-national projects in political science.

Most scholars agree that what ordinary citizens think about democracy and its institutions is a key element of democratization. Indeed, many experts regard 
the mass citizenry's unconditional embrace of democracy as the hallmark of democratic consolidation and the point at which an 'emerging' democracy becomes an 'established' one (Bratton et al., 2004; Diamond, 1999; Rose, 2001). But democracy also depends on continuing public support for its survival and on effective performance in the face of the many challenges that it is likely to encounter (Mishler and Rose, 2001). Only those committed to democracy as the best form of government are likely to reject attempts by anti-democratic movements to overthrow the new democratic regime, especially during a serious, prolonged crisis (Dalton, 1999; Inglehart, 1997). The 20th century contains numerous examples of democracies that failed following internal or external challenges, largely because of widespread popular support for the system was wanting.

But what constitutes widespread public support for democracy? What are its mainsprings and how does it vary according to differing institutional arrangements? While scholars disagree about many aspects of public support for democracy, there is general agreement that popular support for democracy is a highly complex phenomenon which is in a constant state of change (Klingemann, 1999; Shin, 1999). This is especially the case in new democracies, which often retain a legacy of authoritarianism and where the norms, values and practices of democracy are still unfamiliar to many citizens. For example, at one level, citizens are likely to view democracy as an ideal political type, but at another level, it is an operating political system that they observe and interact with on a daily basis. Each perspective will impact in different ways on how voters express their support for democracy, and in turn affect how resilient that support is if it comes under threat or sustained challenge. There is also, as empirical research has demonstrated, a significant disjuncture between the two perspectives (for a review, see Norris, 1999).

These are the main questions that this special symposium seeks to address, by approaching the problem of democratic support from three perspectives: popular satisfaction with democracy; accountability and system performance; and widespread participation from social groups. All of the articles use the Comparative Study of Electoral Systems data set. Most of the articles rely on Module 2 of the CSES data set, although several also pool Modules 1 and 2 in order to maximize the number of countries in the analysis.

Popular satisfaction with democracy is affected by many factors. Kees Aarts and Jacques Thomassen approach the question from the perspective of institutions and highlight the inherent tension between the elections as a mechanism for ensuring accountability, and the ability of elections to provide a mirror to the electorate. Bernhard Wessels and Hermann Schmitt also approach the question of popular satisfaction with democracy by combining institutional design with micro-level factors what they call 'the political supply structure.' Their concern is with the quality of the electoral choices that voters are regularly offered, and in the political consequences that ensue if meaningful political choices are absent.

The second perspective on democratic support focuses on accountability and system performance, in terms of how effective systems are in providing good governance. Gabor Toka re-evaluates the argument that political systems that have electorates with higher levels of information produce better governance, while the roots of democratic legitimacy in system performance is the topic of the paper by Min-hua Huang, Yu-tzung Chang and Yun-han Chu. Jack Vowles adds a further dimension to the question of system performance by examining how far economic globalization leads to popular perceptions of policy convergence between political parties, in turn restricting voters' choices at elections.

The third perspective on democratic support deals with political participation and engagement. While there has been much research on the causes of political participation, there is less scholarly work on its consequences, and specifically on its cognitive consequences. Ken'ichi Ikeda, Tetsuro Kobayashi and Maasa Hosimoto rectify this omission by examining the consequences of participation for political efficacy. The influence of electoral arrangements and political knowledge on turnout has hitherto been treated as discrete topics in the voting literature. Stephen Fisher, Laurence Lessard-Phillips, Sara Hobolt and John Curtice consider the interaction between electoral rules and knowledge in shaping turnout. Finally, Jeffrey Karp and Susan Banducci examine gender differences in political engagement and revisit the argument that the presence of women as candidates and office holders serves to increase women's political engagement.

Established in 1996, the Comparative Study of Electoral Systems is a systematic cross-national project on comparative electoral behaviour involving over 50 countries and more than 200 scholars. The purpose of the project is to advance our understanding of the enduring and fundamental questions about electoral choice in ways not possible through the secondary analysis of existing data. All of the data are freely available from the CSES website, http://www.cses.org/. The website also contains more information about the project, an 
extensive bibliography including many background papers, and links to our national members' projects.

The goals of the CSES project are threefold:

- to illuminate how electoral institutions constrain the beliefs and behaviours of citizens, thereby conditioning the nature and quality of democratic choice as expressed through popular elections;

- to understand the nature of political and social cleavages and alignments; and

- to shed light on how citizens, living under diverse political arrangements, evaluate democratic institutions and processes.

The power of the CSES study design rests in the combination of longitudinal data collection in member countries with data relating to institutional arrangements and the behaviour of voters. This research design enables us to advance our understanding of how variations in institutional structures shape the conduct of elections and affect the nature and quality of democratic choice. Only through comparative analysis, where citizens are observed in different settings, can the impact of political institutions be properly established.

The first round of data collection (Module 1), examining the impact of constitutional and electoral institutions on the performance of democracy, was completed in 2001 , with 33 countries participating. These issues are important for understanding the politics of established democracies, but they are even more important in newly democratizing countries where the choice of electoral and constitutional structures is not fully resolved (see, for example, Lijphart, 1999; Shugart and Carey, 1992; Cox, 2002). Module 1 also included consistent measures of social cleavages - principally occupation, social status and religion - in order to address ongoing debates about the social underpinnings of party systems and whether or not the link between party and society is in long-term decline (see, for example, Evans, 1999; Franklin et al., 1992). The instrument also included items designed to measure attitudes toward parties, political institutions and the democratic process generally.

Module 2, which was designed to tackle questions relating to accountability and representation in the operation of democracy, was completed in 38 countries in 2006. One central question in research on democracy concerns whether elections are a mechanism to hold government accountable for their decisions while in office, or if elections are a means to ensure that citizens' views are properly represented in the democratic process (Powell, 2000). The survey included a range of questions to measure voters' views on this issue. A second question covered by the module relates to the ongoing decline in engagement and participation in politics, which has affected virtually all of the main democracies (see, for example, Dalton and Wattenberg, 2000; Blais, 2000; Franklin, 2004). And a third question covered by the module is the relationship between institutional context and voter choice, and in particular how voters in new democracies reach their political decisions.

Module 3, on political choices, entered the field in late 2006. It is designed to refine models of electoral choice by considering how voters arrive at their party choice. One aspect of how electoral choices are arrived at is whether the choice is based on a retrospective or a prospective judgement. The former is usually based on policy evaluations, the latter on party manifestoes and other election campaign material. A second dimension to the topic is how voters use ideological differences between parties to arrive at a choice, and how such use may depend, for example, on the type of party system or on different electoral arrangements. And a third dimension is the role that performance evaluations may play in electoral choices, involving evaluations of trust and competence among the main political actors.

The absence of meaningful political choices for voters has a particular resonance for democracy. If the available political choices are seen to be limited (through, for example, choices relating to policy, ideology or competence) then voters may simply not bother participating, and almost all democracies have seen a substantial decline in turnout in recent years. Limited political choices for voters will also lead to the rise of minor parties and candidates seeking to mobilize voters on neglected issues that voters (but parties) see as important. And ultimately, if political choices are restricted over a long period, political support for the democratic system itself may decline.

Preliminary releases of Module 3 will be regularly available through the CSES website, with the final release occurring in 2010. When that takes place, we will then have three discrete data sets addressing three key areas of democracy - performance, support and choice - together with some common items that will enable researchers to track the health of democracy across time. If the 21 st century is destined to be the century of democracy, we will at least have some in-depth data with which to benchmark its development.

\section{References}

Blais, A., 2000. To Vote or Not to Vote?: the Merits and Limits of Rational Choice Theory. University of Pittsburgh Press, Pittsburgh. 
Bratton, M., Mattes, R., Gyimah-Boadi, E., 2004. Public Opinion, Democracy, and Market Reform in Africa. Cambridge University Press, New York.

Cox, G., 2002. Making Votes Count: Strategic Coordination in the World's Electoral Systems. Cambridge University Press, New York.

Dalton, R.J., 1999. Political support in advanced industrial democracies. In: Norris, P. (Ed.), Critical Citizens: Global Support for Democratic Governance. Oxford University Press, Oxford.

Dalton, R.J., Wattenberg, M.P., 2000. Parties Without Partisans: Political Change in Advanced Industrial Democracies. Oxford University Press, Oxford.

Diamond, L., 1999. Developing Democracy: toward Consolidation. Yale University Press, New Haven.

Doreenspleet, R., 2000. Reassessing the three waves of democratization. World Politics 52, 384-406.

Evans, G., 1999. The End of Class Politics? Class Voting in Comparative Context. Oxford University Press, Oxford.

Franklin, M.N., 2004. Voter Turnout and the Dynamics of Electoral Competition in Established Democracies since 1945. Cambridge University Press, Cambridge.

Franklin, M.N., Mackie, T., Valen, H., 1992. Electoral Change. Responses to Evolving Social and Attitudinal Structures in Western Countries. Cambridge University Press, Cambridge.
Freedom House, 2007. Freedom in the World 2006: the Annual Survey of Political Rights and Civil Liberties. Freedom House, Washington DC.

Huntington, S.H., 1991. The Third Wave: Democratization in the Late Twentieth Century. University of Oklahoma Press, Norman, OK. Inglehart, R., 1997. Modernization and Postmodernization. Princeton University Press, Princeton.

Klingemann, H.-D., 1999. Mapping political support in the 1990s: a global analysis. In: Norris, P. (Ed.), Critical Citizens: Global Support for Democratic Governance. Oxford University Press, Oxford.

Lijphart, A., 1999. Patterns of Democracy. Government Forms and Performance in Thirty-six Countries. Yale University Press, New Haven.

Mishler, W., Rose, R., 2001. Political support for incomplete democracies. International Political Science Review 22, 303-320.

Norris, P., 1999. Critical Citizens: Global Support for Democratic Governance. Oxford University Press, Oxford.

Powell, G.B., 2000. Elections as Instruments of Democracy: Majoritarian and Proportional Visions. Yale University Press, New Haven.

Rose, R., 2001. A diverging Europe. Journal of Democracy 12, 93-106.

Shin, D.C., 1999. Mass Politics and Culture in Democratizing Korea. Cambridge University Press, New York.

Shugart, M., Carey, J.M., 1992. Presidents and Assemblies: Constitutional Design and Electoral Dynamics. Cambridge University Press, Cambridge. 